\title{
Zebrafish: An In Vivo Model for the Study of Therapeutic Targets of Epilepsy
}

\author{
Brindha Durairaj* and Ravikumar Manish
}

Department of Biochemistry, PSG College of Arts \& Science, Coimbatore, Tamil Nadu, India

\begin{abstract}
Epilepsy is a common neurological disorder due to excessive brain cell activity. It is characterized by unpredictable seizures resulting in cognition. The release of abnormal electric discharge in the regions of the brain causes epileptic seizures. Neurotransmitters play an important role in normal functioning of the brain and thus alteration of these neurotransmitters are associated with epilepsy. Zebrafish model have recently become a focus for various neurological disorders because of its high genetic similarity when compared with those of humans. Zebrafish can be grown in large numbers and their embryos are optically clear allowing examination of individual genes. This review will look at the utility of the zebrafish in the study of various therapeutic targets of epilepsy such as GABA (gamma-aminobutyric acid), AMPA, NMDA (N-methyl-d-aspartate), histamine H3, and phosphodiesters.
\end{abstract}

Keywords: epilepsy; seizures; neurotransmitters; zebrafish; therapeutic targets

Citation: Durairaj, B., \& Manish, R. (2019). Zebrafish: An in vivo model for the study of therapeutic targets of epilepsy. NeuroRegulation, 6(4), 190-196. https://doi.org/10.15540/nr.6.4.190

*Address correspondence to: Dr. Brindha Durairaj, Professor and Principal, Department of Biochemistry, PSG College of Arts \& Science, Coimbatore-641014, Tamil Nadu, India. Email: brindhavenkatesh6@gmail.com

Copyright: (C) 2019. Durairaj and Manish. This is an Open Access article distributed under the terms of the Creative Commons Attribution License (CC-BY).

\section{Edited by:}

Rex L. Cannon, PhD, SPESA Research Institute, Knoxville, Tennessee, USA

\section{Reviewed by:}

Tanju Surmeli, MD, Living Health Center for Research and Education, Sisli, Istanbul, Turkey

Nancy L. Wigton, PhD, Grand Canyon University, Phoenix, Arizona, USA

\section{Introduction}

Epilepsy is a common neurological disorder which causes biomedical disturbance resulting in abnormal electrical activity in certain neurons, which may further affect the entire brain. This abnormal neuronal activity has a significant influence in cognitive dysfunction and mental health condition (Kwan \& Brodie, 2001; Meador, 2002; Smith, Craft, Collins, Mattson, \& Cramer, 1986). An epileptic seizure is a sign of abnormal activity in neurons which is spontaneous. The effect of chemical reaction in the brain produces electrical discharges, and thus the disturbance of excitation and inhibition in a region of brain when moved too far in the direction of excitation results in seizures (Dekker, 2002).
The classification of epileptic seizures is divided into three categories (generalized, focal, and epileptic spasms) depending upon the release of abnormal electric discharge in the region of brain. Generalized seizures affect both hemispheres of the brain; focal seizures are limited to one hemisphere yet may progress to generalized seizures (Berg \& Millichap, 2013). A seizure is accompanied with imbalance excitation and inhibition in the brain, resulting in alteration of brain functioning and genes. The imbalance leading to epilepsy can occur anywhere from circuit level to receptor level and, in some cases, it might be due to abnormal ionic channel function (Berkovic, 2015). 


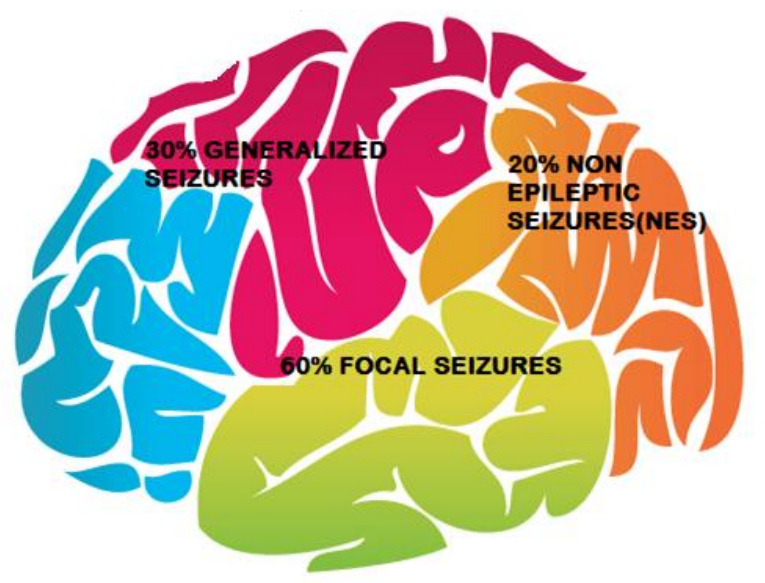

Figure 1. Classification of epileptic seizures upon abnormal electrical discharge in the human brain.

Both children and adults with epilepsy are prone to long-term forgetting in which newly acquired memories fade over days and memory impairment in which autobiographical or public facts are forgotten (Butler \& Zeman, 2008). Accelerated long-term forgetting is a condition where individuals learn and initially retain information normally but forget the information at an unusually rapid rate (Blake, Wroe, Breen, \& McCarthy, 2000). Accelerated forgetting has been demonstrated in both adults and children (Butler et al., 2009; Martinos et al., 2012).

Neurotransmitters (gamma-aminobutyric acid [GABA], glutamate, and acetylcholine) are associated with normal functioning of brain. The alteration of these neurotransmitters has a significant role in epilepsy (Sancheti, Shaikh, Khatwani, Kulkarni, \& Sathaye, 2013). GABA is an inhibitory transmitter and helps in suppressing epilepsy, whereas glutamate causes neuronal death. Acetylcholine plays the key role in modulating glutamate release and memory formation (Ozawa, Kamiya, \& Tsuzuki, 1998).

Zebrafish (Danio rerio) has become a widely used model system for the neurobehavioral system. Zebrafish are vertebrates and therefore more closely related to other model organisms and also share a high genetic similarity to humans; approximately $70 \%$ of all human disease genes have functional homologs in zebrafish (Cooper, D’Amico, \& Henry, 1999).

Recent studies have proven that zebrafish possess several advantages over other animal models. Zebrafish are much easier to maintain in a laboratory and can also be grown in large numbers (Kimmel, 1989). The mode of fertilization is external, and their embryos are optically clear allowing examination of individual genes (fluorescently labeled or dyed; Bernasconi, 2004; Cendes, 2005; Kimmel \& Warga 1988; Solnica-Krezel, Stemple, \& Driever, 1995; Tran \& Gerlai, 2015). The small size of zebrafish larvae allows easy manipulation of gene activities and screening of neuroactive compounds (Kuzniecky \& Knowlton, 2002).

The aim of this systematic review summarizes the potential of zebrafish as a model organism to examine various therapeutic targets of epilepsy.
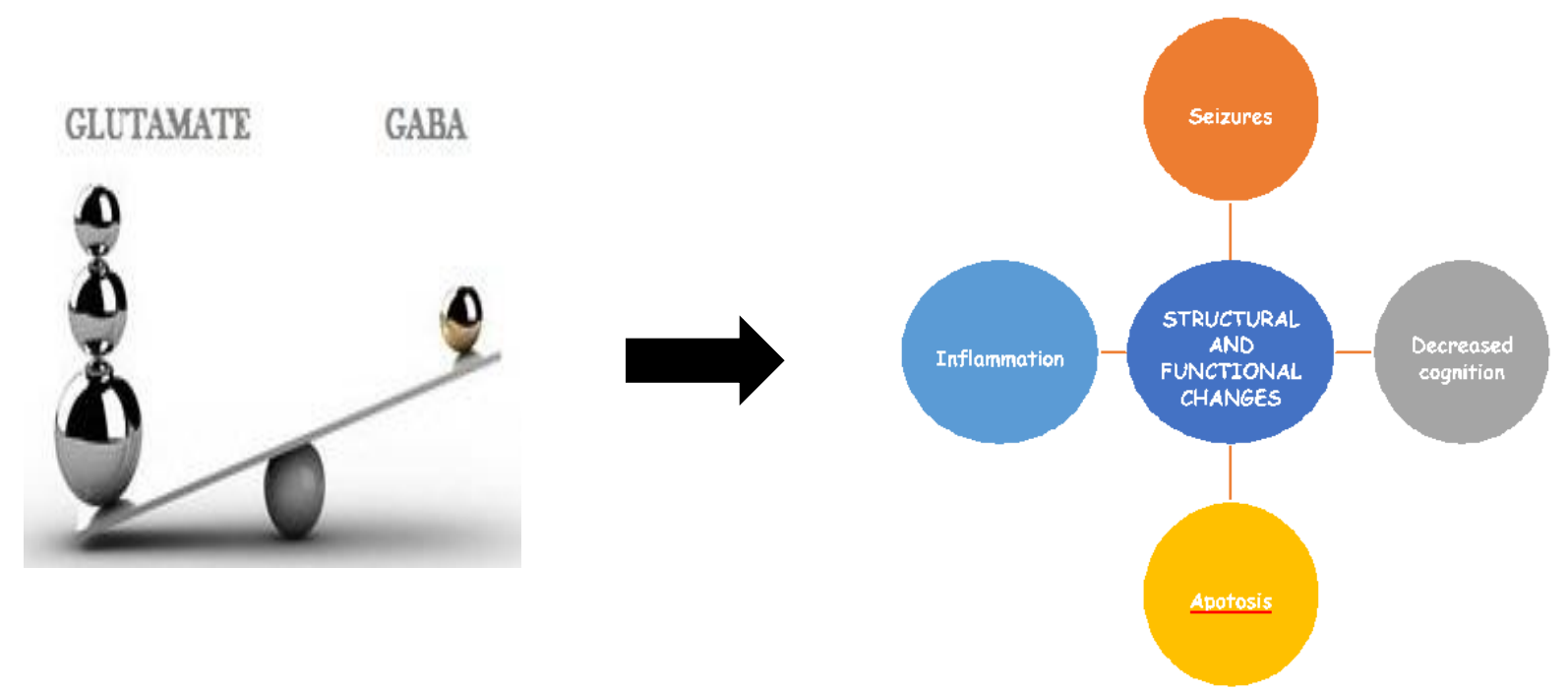

Figure 2. Schematic representation of excitatory and inhibitory neurotransmitter induced changes 


\section{Therapeutic Targets of Epilepsy}

\section{Gamma-Aminobutyric Acid}

GABA is the major inhibitory neurotransmitter of the nervous system (Bowery \& Smart, 2006). It acts through its receptors known as GABA receptors, which are divided into two classes, $G_{A B A}$ and $G A B A_{B}$. $G A B A_{A}$ receptors are chloride channels, while $G A B A_{B}$ receptors belong to class of $G$-protein coupled receptors (GPCR). GABA $A_{A}$ receptors are combinations of 19 different subunits $(\alpha 1-6, \beta 1-3$, $\mathrm{\gamma} 1-3, \delta, \varepsilon, \pi, \theta$, and $\rho 1-3$ ) and are targets for classes of clinically important drugs, such as benzodiazepines and barbiturates (Chua \& Chebib, 2017; Möhler, 2006; Olsen \& Sieghart, 2008).

$G A B A_{B}$ receptors are $G$ protein-linked receptors that decrease calcium entry and have a slow inhibitory effect. The activation of $\mathrm{GABA}_{B}$ receptors is associated with a decrease in neurotransmitter release, and thus $\mathrm{GABA}_{B}$ agonist drugs would have an antiepileptic effect (Swartzwelder, Bragdon, Sutch, Ault \& Wilson, 1986). GABAergic neurons are ubiquitously distributed in the brain that determines the integration of all neuronal functions. Blockade of the fast inhibitory $\mathrm{GABA}_{\mathrm{A}}$ receptors might be the major cause of seizures. It has therefore been suggested that dysfunction of the GABAergic system may have an influence in the development of acute seizures and in the manifestation of epilepsy syndromes (Möhler, 2006).

Zebrafish contain at least 23 different $G_{A B A}$ receptor subunits. Although we observed some differences between the zebrafish and mammalian $G_{A B A}$ receptor subunit gene families, zebrafish contain orthologs for most of the $G_{A B A}$ receptor subunits found in mammals. $G_{A B A_{A}}$ receptors are expressed in larval zebrafish and are essential for normal brain function (Baraban, Taylor, Castro, \& Baier, 2005).

\section{Ampa Receptor Potentiators}

Glutamate is the major excitatory neurotransmitter released from nerve cells of the adult mammalian brain that mediates numerous processes. Glutamates are classified into two large subclasses of receptors: the ionotropic glutamate receptors and the metabotropic glutamate receptors. The ionotropic receptors can be further subdivided into AMPA, kainate, and N-methyl-d-aspartic acid (NMDA) receptors (Featherstone, 2010; Meldrum, 2000; Seeburg, 1993). The AMPA receptor comprises four subunits, which include at least two of the following subunit types: GluA1, GluA2, GluA3, or GluA4 (Mansour, Nagarajan, Nehring, Clements, \&
Rosenmund, 2001). AMPA receptors are the major excitatory postsynaptic receptor which are expressed abundantly throughout the central nervous system (CNS; Rogawski, 2011).

Early studies have indicated the pathophysiologic role of AMPA receptors in epilepsy. The blockade of AMPA receptors may have a role in abnormal electrical activity in the epileptic brain (Mansour et al., 2001). The AMPA-receptor subunit expression of human epileptic brain revealed high expression of the GluA1-receptor subunit in the epileptic hippocampus (Graebenitz et al., 2011) which indeed increases the levels of homomeric GluA1 receptor, that exhibits high conductance compared with the GluA2containing $\mathrm{Ca} 2+$-impermeable heteromeric receptors (Coombs, et al., 2012; Ying, Babb, Comair, Bushey, \& Touhalisky, 1998). Neuronal degeneration usually occurs with increased expression of GluA2-lacking calcium permeable receptors, thus AMPA receptors might have a significant role in the pathophysiology of epilepsy: not only the expression of seizures but also the progression of epilepsy (Grossman, Wolfe, Yasuda, \& Wrathall, 1999; Liu \& Zukin, 2007; Swanson, Kamboj, \& Cull-Candy, 1997).

The subunits of AMPA receptors have been expressed in zebrafish with a high degree of similarity when compared to those of humans, rats, and mice. AMPA receptors have been found in different regions of zebrafish (retina, hindbrain, spinal cord, and neurons; Ali, Buss, \& Drapeau, 2000; Patten \& Ali, 2007; Yazulla \& Studholme, 2001). They are also associated with the neuromuscular junction that facilitate acetylcholine release during early development in zebrafish (Todd, Slatter, \& Ali, 2004).

\section{$\mathrm{N}$-Methyl-D-Aspartate Receptors}

$\mathrm{N}$-methyl-d-aspartate receptors (NMDARs) are ligand-gated ionotropic glutamate receptors that are important mediators for neuronal events such as synaptic plasticity, learning and memory, neuronal development and circuit formation, and have been implicated in various neuronal disorders (Cull-Candy, Brickley \& Farrant, 2001; Hua \& Smith, 2004). The mammalian NMDA receptor was first cloned in 1991 (Moriyoshi et al., 1991), and its structure and function has been studied widely in mammals. These receptors are highly permeable to calcium and, thus, may play important regulatory roles in the response of neurons to signaling (Mayer \& Armstrong, 2004; Riedel, Platt, \& Micheau, 2003).

There are five NMDA receptor genes expressed in mammals encoding for NMDAR1 (NR1) and NMDAR2 (NR2) subunits (Cox, Kucenas, \& Voigt, 
2005). The NR1 subunit are widely distributed throughout the CNS, which plays an important role in voltage independent zinc inhibition, whereas the NR2 subunits exhibit cell-specific expression patterns. Pharmacological regulation of the NMDAR depends on effects on unique combinations of subunit-specific binding sites. Both the NR1 and NR2 subunits contribute to the formation of the NMDAR ion channel. The glutamate-binding site is on the NR2 subunits, and the glycine-binding site is located on the NR1 subunits. The glycine (and/or D-serine) coagonist site must be the pathogenesis of epileptic discharges (Carter, Deshpande, Rafiq, Sombati, \& DeLorenzo, 2010).

The subunits NR1 and NR2 of NMDA receptor have been expressed in zebrafish and the similarity between subunits of zebrafish when compared to those of human showed high degree of identity (NR1 subunit expressed $90 \%$ identity and NR2 receptors expressed 50-90\% identity; Cox et al., 2005).

\section{Histamine 3 Receptor Antagonists}

The histamine neuroreceptor system is one of the major excitatory neurotransmitters exerting key neurological functions including alertness and sleep, seizure threshold, hormone secretion, and pain (Brown, Stevens, \& Hans, 2001; Haas \& Panula, 2003; Schwartz, Arrang, Garbarg, Pollard, \& Ruat, 1991). Histamine belongs to a large superfamily of GPCRs that are characterized by the presence of seven transmembrane domains (Leurs, Bakker, Timmerman, \& de Esch, 2005). The histamine H3 receptor (H3R), which is particularly expressed in the CNS and specifically in the brain, has led to the development of numerous antagonists/inverse agonists for the potential treatment of brain (MartinezMir et al., 1990). H3R is a presynaptic auto-receptor on histamine neurons and a heteroreceptor which modulates the activity of various neurotransmitters such as histamine, acetylcholine, noradrenaline, dopamine, serotonin, and GABA (Sander, Kottke, \& Stark, 2008; Schlicker, Betz, \& Göthert, 1988). Low levels of histamine are usually associated with convulsions (Kiviranta, Tuomisto, \& Airaksinen, 1995; Tuomisto \& Tacke, 1986).

The nonimidazole class has the potential to penetrate the brain more easily than those with an imidazole ring and, accordingly, H3R antagonists/inverse agonists have been targeted for a broad spectrum of brain diseases; for example, Alzheimer's disease, dementia, stroke, mood and sleep disorders, attention-deficit disorders, schizophrenia, narcolepsy, anxiety, depression, and epilepsy (Bahi, Sadek, Schwed, Walter, \& Stark, 2013; Bhowmik, Khanam, \&
Vohora, 2012; Inocente et al., 2012; Kuhne, Wijtmans, Lim, Leurs, \& de Esch, 2011; Leurs, Vischer, Wijtmans, \& de Esch, 2011; Sadek et al., 2013). Furthermore, ligands for the H3R are now in clinical studies and some companies have H3R antagonists for phase 1 and phase 2 clinical trials under review that could offer potential treatment for Alzheimer's disease, schizophrenia, epilepsy, narcolepsy, obesity, neuropathic pain, and allergic rhinitis (Micallef, Stark, \& Sasse, 2013; Peitsaro, Sundvik, Anichtchik, Kaslin, \& Panula, 2007).

Histamine receptors have been cloned and expressed in zebrafish in which H3R is expressed throughout the zebrafish brain especially in the region of optic tectum and hypothalamus, and receptor peptide sequence showed $50 \%$ identity in comparison to human (Griffin et al., 2017; Peitsaro, Anichtchik, \& Panula, 2000). A recent study has demonstrated the role of clemizole (a histamine antagonist) as a potent inhibitor of seizures activity in zebrafish (Cofiel \& Mattioli, 2006).

\section{Phosphodiesterases}

Cyclic AMP (cAMP) and/or cyclic guanosine monophosphate (cGMP) are hydrolyzed by Phosphodiesterase (PDEs) that contains 11 isozymes encoded by 21 genes in mammals (Bender \& Beavo, 2006; Seeger et al., 2003). PDE10A are found in multiple regions of the brain in mammalian species. The upregulation of cAMP and cGMP concentrations in different regions of brain is due to the inhibition of PDE10A (Francis, Blount, \& Corbin, 2011; Grauer et al., 2009; Suzuki, Harada, Suzuki, Miyamoto, \& Kimura, 2016). The presence of PDE10A in different regions of mammalian brain, suggests that it has various functions in the CNS (Leuti et al., 2013; Liddie, Anderson, Paz, \& Itzhak, 2012). Several studies have clearly demonstrated the importance of PDE10A in the treatment of neurological and psychiatric disorders. The inhibition of PDE10A has proved as a promising candidate for the treatment of schizophrenia in animal or preclinical research (Siuciak et al., 2006). PDE10A may be involved in the pathophysiology of various neurological and psychiatric disorders (Giralt et al., 2013).

In zebrafish, 2',3'-cyclic-nucleotide 3'phosphodiesterase was first reported as being induced during optic nerve regeneration study (Chang, Chandler, Williams, \& Walker, 2010). Recent investigations have provided information of two enzymes of primary interest PDE4 and PDE10A which have a high percentage of identity to that of humans (Ballestero, Dybowski, Levy, Agranoff, \& 
Uhler, 1999). Clearly more investigations are needed to elucidate the distribution of PDEs in fish and their role epilepsy.

\section{Conclusion}

Animal models are considered as a useful tool for investigating the cause and pathology of human disease, yet to develop an animal model for brain disorder, particularly epilepsy, is very difficult because of its disease complexity. It is now recognized that zebrafish possess a great deal of similarity to mammals and are highly advantageous with their unique properties such as external fertilization, small size, as well as optical clarity of embryos. The central role of receptors in epilepsy demonstrates the potential utility of targets to control seizures. In this review we have discussed various pharmacological targets which are being investigated preclinically for epilepsy-GABA, Phosphodiesterase, Histamine 3, NMDA, and AMPA - and have illustrated the use of zebrafish in the assessment of these targets.

\section{Author Disclosure}

Authors have no grants, financial interests, or conflicts to disclose.

\section{References}

Ali, D. W., Buss, R. R., \& Drapeau, P. (2000). Properties of miniature glutamatergic EPSCs in neurons of the locomotor regions of the developing zebrafish. Journal of Neurophysiology, 83(1), 181-191. https://doi.org/10.1152 /jn.2000.83.1.181

Bahi, A., Sadek, B., Schwed, S. J., Walter, M., \& Stark, H. (2013). Influence of the novel histamine $\mathrm{H} 3$ receptor antagonist ST1283 on voluntary alcohol consumption and ethanolinduced place preference in mice. Psychopharmacology, 228(1), 85-95. https://doi.org/10.1007/s00213-013-3019-7

Ballestero, R. P., Dybowski, J. A., Levy, G., Agranoff, B. W., \& Uhler, M. D. (1999). Cloning and characterization of $z R I C H, a$ 2',3'-cyclic-nucleotide 3'-phosphodiesterase induced during zebrafish optic nerve regeneration. Journal of Neurochemistry, 72(4), 1362-1371. https://doi.org/10.1046/j.14714159.1999.721362.x

Baraban, S. C., Taylor, M. R., Castro, P. A., \& Baier, H. (2005). Pentylenetetrazole induced changes in zebrafish behavior, neural activity and c-fos expression. Neuroscience, 131(3), 759-768. https://doi.org/10.1016/j.neuroscience.2004.11.031

Bender, A. T., \& Beavo, J. A. (2006). Cyclic nucleotide phosphodiesterases: Molecular regulation to clinical use. Pharmacological Reviews, 58(3), 488-520. https://doi.org $/ 10.1124 /$ pr.58.3.5

Berg, A. T., \& Millichap, J. J. (2013). The 2010 revised classification of seizures and epilepsy. Continuum: Lifelong Learning in Neurology, 19(3), 571-597. https://doi.org/10.1212 101.CON.0000431377.44312.9e

Berkovic, S. F. (2015). Genetics of epilepsy in humans. Cold Spring Harbor Laboratory Perspectives in Medicine. https://doi.org /10.1101/cshperspect.a022400
Bernasconi, A. (2004). Quantitative MR imaging of the neocortex. Neuroimaging Clinics of North America, 14(3), 425-436. https://doi.org/10.1016/j.nic.2004.04.013

Bhowmik, M., Khanam, R., \& Vohora, D. (2012). Histamine H3 receptor antagonists in relation to epilepsy and neurodegeneration: A systemic consideration of recent progress and perspectives. British Journal of Pharmacology 167(7), 1398-1414. https://doi.org/10.1111/j.14765381.2012.02093.x

Blake, R. V., Wroe, S. J., Breen, E. K., \& McCarthy, R. A. (2000). Accelerated forgetting in patients with epilepsy: Evidence for an impairment in memory consolidation. Brain, 123(3), 472483. https://doi.org/10.1093/brain/123.3.472

Bowery, N. G., \& Smart, T. G. (2006). GABA and glycine as neurotransmitters: A brief history. British Journal of Pharmacology, 147(1), 109-119. https://doi.org/10.1038 /sj.bjp.0706443

Brown, R. E., Stevens, D. R., \& Haas, H. L. (2001). The physiology of brain histamine. Progress in Neurobiology, 63(6), 637-672. https://doi.org/10.1016/S0301-0082(00)00039-3

Butler, C. R., Bhaduri, A., Acosta-Cabronero, J., Nestor, P. J., Kapur, N., Graham, K. S., ... Zeman, A. Z. (2009). Transient epileptic amnesia: Regional brain atrophy and its relationship to memory deficits. Brain, 132(2), 357-368. https://doi.org /10.1093/brain/awn336

Butler, C. R., \& Zeman, A. Z. (2008). Recent insights into the impairment of memory in epilepsy: Transient epileptic amnesia, accelerated long-term forgetting and remote memory impairment. Brain, 131(9), 2243-2263. https://doi.org /10.1093/brain/awn127

Carter, D. S., Deshpande, L. S., Rafiq, A., Sombati, S., \& DeLorenzo, R. J. (2010). Characterization of spontaneous recurrent epileptiform discharges in hippocampal-entorhinal cortical slices prepared from chronic epileptic animals. Seizure, 20(3), 218-224. https://doi.org/10.1016/j.seizure.2010.11.022

Cendes, F. (2005). Progressive hippocampal and extrahippocampal atrophy in drug resistant epilepsy. Current Opinion in Neurology, 18(2), 173-177. https://doi.org/10.1097 101.wco.0000162860.49842.90

Chang, P., Chandler, K. E., Williams, R. S., \& Walker, M. C. (2010). Inhibition of long-term potentiation by valproic acid through modulation of cyclic AMP. Epilepsia, 51(8) 1533-1542. https://doi.org/10.1111/j.1528-1167.2009.02412.x

Chua, H. C., \& Chebib, M. (2017). GABAA receptors and the diversity in their structure and pharmacology. Advances in Pharmacology, 79, 1-34. https://doi.org/10.1016 /bs.apha.2017.03.003

Cofiel, L. P., \& Mattioli, R. (2006). Involvement of histamine receptors in the acquisition of inhibitory avoidance in Carassius auratus. Progress in Neuro-Psychopharmacology and Biological Psychiatry, 30(7), 1246-1250. https://doi.org /10.1016/j.pnpbp.2006.03.017

Coombs, I. D., Soto, D., Zonouzi, M., Renzi, M., Shelley, C., Farrant, M., \& Cull-Candy, S.G. (2012). Cornichons modify channel properties of recombinant and glial AMPA receptors. The Journal of Neuroscience, 32(29), 9796-9804. https://doi.org/10.1523/JNEUROSCI.0345-12.2012

Cooper, M. S., D’Amico, L. A., \& Henry, C. A. (1999). Confocal microscopic analysis of morphogenetic movements. Methods in Cell Biology, 59, 179-204. https://doi.org/10.1016/S0091$679 \times(08) 61826-9$

Cox, J. A., Kucenas, S., \& Voigt, M. M. (2005). Molecular characterization and embryonic expression of the family of $\mathrm{N}$ Methyl-D Aspartate receptor subunit genes in the zebrafish. Developmental Dynamics, 234(3), 756-766. https://doi.org $/ 10.1002 / d v d y .20532$

Cull-Candy, S., Brickley, S., \& Farrant, M. (2001). NMDA receptor subunits: Diversity, development and disease. Current Opinion in Neurobiology, 11(3), 327-335. https://doi.org/10.1016 IS0959-4388(00)00215-4 
Dekker, P. A. (2002). Epilepsy: A manual to medical \& clinical officers in Africa (Rev. 2nd ed.). Geneva: World Health Organization.

Featherstone, D. E. (2010). Intercellular glutamate signaling in the nervous system and beyond. ACS Chemistry Neuroscience, 1(1), 4-12. https://doi.org/10.1021/cn900006n

Francis, S. H., Blount, M. A., \& Corbin, J. D. (2011). Mammalian cyclic nucleotide phosphodiesterases: Molecular mechanisms and physiological functions. Physiological Reviews, 91(2), 651-690. https://doi.org/10.1152/physrev.00030.2010

Giralt, A., Saavedra, A., Carretón, O., Arumí, H., Tyebji, S., Alberch, J., \& Pérez-Navarro, E. (2013). PDE10 inhibition increases GluA1 and CREB phosphorylation and improves spatial and recognition memories in a Huntington's disease mouse model. Hippocampus, 23(8), 684-695. https://doi.org /10.1002/hipo.22128

Graebenitz, S., Kedo, O., \& Speckmann, E.-J., Gorji, A., Panneck, H., Hans, V., ... Pape, H.-C. (2011). Interictal-like network activity and receptor expression in the epileptic human lateral amygdala. Brain, 134(10), 2929-2947. https://doi.org/10.1093 /brain/awr202

Grauer, S. M., Pulito, V. L., Navarra, R. L., Kelly, M. P., Kelley, C., Graf, R., ... Brandon, N. J. (2009). Phosphodiesterase 10A inhibitor activity in preclinical models of the positive, cognitive, and negative symptoms of schizophrenia. Journal of Pharmacology and Experimental Therapeutics, 331(2), 574590. https://doi.org/10.1124/jpet.109.155994

Griffin, A., Hamling, K. R., Knupp, K., Hong, S., Lee, L. P., \& Baraban, S. C. (2017). Clemizole and modulators of serotonin signalling suppress seizures in Dravet syndrome. Brain, 140(3), 669-683. https://doi.org/10.1093/brain/aww342

Grossman, S. D., Wolfe, B. B., Yasuda, R. P., \& Wrathall, J. R. (1999). Alterations in AMPA receptor subunit expression after experimental spinal cord contusion injury. Journal of Neuroscience, 19(14), 5711-5720. https://doi.org/10.1523 /JNEUROSCI.19-14-05711.1999

Haas, H., \& Panula, P. (2003). The role of histamine and the tuberomamillary nucleus in the nervous system. Nature Reviews Neuroscience, 4, 121-130. https://doi.org/10.1038 /nrn1034

Hua, J. Y., \& Smith, S. J. (2004). Neural activity and the dynamics of central nervous system development. Nature Neuroscience, 7, 327-332. https://doi.org/10.1038/nn1218

Inocente, C., Arnulf, I., Bastuji, H., Thibault-Stoll, A., Raoux, A., Reimão, R., ... Franco, P. (2012). Pitolisant, an inverse agonist of the histamine $\mathrm{H} 3$ receptor: An alternative stimulant for narcolepsy-cataplexy in teenagers with refractory sleepiness. Clinical Neuropharmacology, 35(2), 55-60. https://doi.org /10.1097/WNF.0b013e318246879d

Kimmel, C. B. (1989). Genetics and early development of zebrafish. Trends in Genetics, 5, 283-288. https://doi.org /10.1016/0168-9525(89)90103-0

Kimmel, C. B. \& Warga, R. M. (1988). Cell lineage and developmental potential of cells in the zebrafish embryo. Trends in Genetics, 4(3), 68-74. https://doi.org/10.1016/01689525(88)90043-1

Kiviranta, T., Tuomisto, L., \& Airaksinen, E. M. (1995). Histamine in cerebrospinal fluid of children with febrile convulsions. Epilepsia, 36(3), 276-280. https://doi.org/10.1111/j.15281157.1995.tb00996.x

Kuhne, S., Wijtmans, M., Lim, H. D., Leurs, R., \& de Esch, I. J. (2011). Several down, a few to go: Histamine H3 receptor ligands making the final push towards the market? Expert Opinion on Investigational Drugs, 20(12), 1629-1648. https://doi.org/10.1517/13543784.2011.625010

Kuzniecky, R. I., \& Knowlton, R. C. (2002). Neuroimaging of epilepsy. Seminars in Neurology, 22(3), 279-288. https://doi.org/10.1055/s-2002-36647
Kwan, P., \& Brodie, M. J. (2001). Neuropsychological effects of epilepsy and antiepileptic drugs. The Lancet, 357(9251), 216222. https://doi.org/10.1016/S0140-6736(00)03600-X

Leurs, R., Bakker, R. A., Timmerman, H., \& de Esch, I. J. (2005). The histamine $\mathrm{H} 3$ receptor: From gene cloning to $\mathrm{H} 3$ receptor drugs. Nature Reviews Drug Discovery, 4, 107-120. https://doi.org/10.1038/nrd1631

Leurs, R., Vischer, H. F., Wijtmans, M., \& de Esch, I. J. (2011). En route to new blockbuster anti-histamines: Surveying the offspring of the expanding histamine receptor family. Trends in Pharmacological Sciences, 32(4), 250-257. https://doi.org /10.1016/j.tips.2011.02.004

Leuti, A., Laurenti, D., Giampà, C., Montagna, E., Dato, C., Anzilotti S., ... Fusco, F. R. (2013). Phosphodiesterase 10A (PDE10A) localization in the R6/2 mouse model of Huntington's disease. Neurobiology of Disease, 52, 104-116. https://doi.org/10.1016 /j.nbd.2012.11.016

Liddie, S., Anderson, K. L., Paz, A., \& Itzhak, Y. (2012). The effect of phosphodiesterase inhibitors on the extinction of cocaineinduced conditioned place preference in mice. Journal of Psychopharmacology, 26(10), 1375-1382. https://doi.org $/ 10.1177 / 0269881112447991$

Liu, S. J., \& Zukin, R. S. (2007). $\mathrm{Ca}^{2+}$-permeable AMPA receptors in synaptic plasticity and neuronal death. Trends in Neurosciences, 30(3), 126-134. https://doi.org/10.1016 /j.tins.2007.01.006

Mansour, M., Nagarajan, N., Nehring, R. B., Clements, J. D., \& Rosenmund, C. (2001). Heteromeric AMPA receptors assemble with a preferred subunit stoichiometry and spatial arrangement. Neuron, 32(5), 841-853. https://doi.org/10.1016 /S0896-6273(01)00520-7

Martinez-Mir, M. I., Pollard, H., Moreau, J., Arrang, J. M., Ruat, M., Traiffort, E., ... Palacios, J. M. (1990). Three histamine receptors $(\mathrm{H} 1, \mathrm{H} 2$ and $\mathrm{H} 3)$ visualized in the brain of human and non-human primates. Brain Research, 526(2), 322-327. https://doi.org/10.1016/0006-8993(90)91240-h

Martinos, M. M., Yoong, M., Patil, S., Chin, R. F., Neville, B. G., Scott, R. C., \& de Haan, M. (2012). Recognition memory is impaired in children after prolonged febrile seizures. Brain, 135(10), 3153-3164. https://doi.org/10.1093/brain/aws213

Mayer, M. L., \& Armstrong, N. (2004). Structure and function of glutamate receptor ion channels. Annual Review of Physiology, 66, 161-181. https://doi.org/10.1146 /annurev.physiol.66.050802.084104

Meador, K. J. (2002). Cognitive outcomes and predictive factors in epilepsy. Neurology, 58(8, Suppl. 5), S21-S26. https://doi.org /10.1212/wnl.58.8_suppl_5.s21

Meldrum, B. S. (2000). Glutamate as a neurotransmitter in the brain: Review of physiology and pathology. The Journal of Nutrition, 130(Suppl. 4S), 1007S-1015S. https://doi.org $/ 10.1093 / \mathrm{jn} / 130.4 .1007 \mathrm{~S}$

Micallef, S., Stark, H., \& Sasse, A. (2013). Polymorphisms and genetic linkage of histamine receptors. Life Sciences, 93(15), 487-494. https://doi.org/10.1016/j.lfs.2013.08.012

Möhler, H. (2006). GABA(A) receptor diversity and pharmacology. Cell and Tissue Research, 326(2), 505-516. https://doi.org /10.1007/s00441-006-0284-3

Moriyoshi, K., Masu, M., Ishii, T., Shigemoto, R., Mizuno, N., \& Nakanishi, S. (1991). Molecular cloning and characterization of the rat NMDA receptor. Nature, 354, 31-37. https://doi.org $/ 10.1038 / 354031 \mathrm{a} 0$

Olsen, R. W., \& Sieghart, W. (2008). International Union of Pharmacology. LXX. Subtypes of gamma-aminobutyric acid(A) receptors: Classification on the basis of subunit composition, pharmacology and function. Pharmacolological Reviews, 60(3), 243-260. https://doi.org/10.1124/pr.108.00505

Ozawa, S., Kamiya, H., \& Tsuzuki, K. (1998). Glutamate receptors in the mammalian central nervous system. Progress in Neurobiology, 54(5), 581-618. https://doi.org /10.1016/S03010082(97)00085-3 
Patten, S. A., \& Ali, D. W. (2007). AMPA receptors associated with zebrafish Mauthner cells switch subunits during development. Journal of Physiology, 581(3), 1043-1056. https://doi.org /10.1113/jphysiol.2007.129999

Peitsaro, N., Anichtchik, O. V., \& Panula, P. (2000). Identification of a histamine $\mathrm{H}(3)$-like receptor in the zebrafish (Danio rerio) brain. Journal of Neurochemistry, 75(2), 718-724. https://doi.org/10.1046/j.1471-4159.2000.0750718.x

Peitsaro, N., Sundvik, M., Anichtchik, O. V., Kaslin, J., \& Panula, P. (2007). Identification of zebrafish histamine $\mathrm{H} 1, \mathrm{H} 2$ and $\mathrm{H} 3$ receptors and effects of histaminergic ligands on behavior. Biochemical Pharmacology, 73(8), 1205-1214. https://doi.org /10.1016/j.bcp.2007.01.014

Riedel, G., Platt, B., \& Micheau, J. (2003). Glutamate receptor function in learning and memory. Behavioural Brain Research, 140(1-2), 1-47. https://doi.org/10.1016/S01664328(02)00272-3

Rogawski, M. A. (2011). Revisiting AMPA receptors as an antiepileptic drug target. Epilepsy Currents, 11(2), 56-63. https://doi.org/10.5698/1535-7511-11.2.56

Sadek, B., Shehab, S., Więcek, M., Subramanian, D., Shafiullah, M., Kieć-Kononowicz, K., \& Adem, A. (2013). Anticonvulsant properties of histamine $\mathrm{H} 3$ receptor ligands belonging to $\mathrm{N}$ substituted carbamates of imidazopropanol. Bioorganic \& Medicinal Chemistry Letters, 23(17), 4886-4891. https://doi.org/10.1016/j.bmcl.2013.06.075

Sancheti, J. S., Shaikh, M. F., Khatwani, P. F., Kulkarni, S. R., \& Sathaye, S. (2013). Development and validation of a HPTLC method for simultaneous estimation of L-glutamic acid and $\mathrm{Y}^{-}$ aminobutyric acid in mice brain. Indian Journal of Pharmaceutical Sciences, 75(6), 716-721. https://doi.org /10.4103/0250-474X.124797

Sander, K., Kottke, T., \& Stark H. (2008). Histamine H3 receptor antagonists go to clinics. Biological and Pharmaceutical Bulletin, 31(12), 2163-2181. https://doi.org/10.1248 /bpb.31.2163

Schlicker, E., Betz, R., \& Göthert, M. (1988). Histamine H3 receptor-mediated inhibition of serotonin release in the rat brain cortex. Naunyn-Schmiedebergs Archives of Pharmacology, 337(5), 588-590. https://doi.org/10.1007 /bf00182737

Schwartz, J. C., Arrang, J. M., Garbarg, M., Pollard, H., \& Ruat, M. (1991). Histaminergic transmission in the mammalian brain. Physiological Reviews, 71(1), 1-51. https://doi.org/10.1152 /physrev.1991.71.1.1

Seeburg, P. H. (1993). The TINS/TiPS lecture the molecular biology of mammalian glutamate receptor channels. Trends in Neurosciences, 16(9), 359-365. https://doi.org/10.1016/01662236(93)90093-2

Seeger, T. F., Bartlett, B., Coskran, T. M., Culp, J. S., James, L. C., Krull, D. L., ... Menniti, F. S. (2003). Immunohistochemical localization of PDE10A in the rat brain. Brain Research, 985(2), 113-126. https://doi.org/10.1016/s0006-8993(03)02754-9
Siuciak, J. A., McCarthy, S. A., Chapin, D. S., Fujiwara, R. A., James, L. C., Williams, R. D., ... Schmidt, C. J. (2006). Genetic deletion of the striatum-enriched phosphodiesterase PDE10A: Evidence for altered striatal function. Neuropharmacology, 51(2), 374-385. $\quad$ https://doi.org/10.1016 /j.neuropharm.2006.01.012

Smith, D. B., Craft, B. R., Collins, J., Mattson, R. H., \& Cramer, J. A. (1986). Behavioral characteristics of epilepsy patients compared with normal controls. Epilepsia, 27(6), 760-768. https://doi.org/10.1111/j.1528-1157.1986.tb03607.x

Solnica-Krezel, L., Stemple, D. L., \& Driever, W. (1995). Transparent things: Cell fates and cell movements during early embryogenesis of zebrafish. Bioessays, 17(11), 931-939. https://doi.org/10.1002/bies.950171106

Suzuki, K., Harada, A., Suzuki, H., Miyamoto, M., \& Kimura, H. (2016). TAK-063, a PDE10A inhibitor with balanced activation of direct and indirect pathways, provides potent antipsychoticlike effects in multiple paradigms. Neuropsychopharmacology, 41, 2252-2262. https://doi.org /10.1038/npp.2016.20

Swanson, G. T., Kamboj, S. K., \& Cull-Candy, S. G. (1997). Singlechannel properties of recombinant AMPA receptors depend on RNA editing, splice variation, and subunit composition. Journal of Neuroscience, 17(1), 58-69. https://doi.org/10.1523 /JNEUROSCI.17-01-00058.1997

Swartzwelder, H. S., Bragdon, A. C., Sutch, C. P., Ault, B., \& Wilson, W. A. (1986). Baclofen suppresses hippocampal epileptiform activity at low concentrations without suppressing synaptic transmission. Journal of Pharmacology and Experimental Therapeutics, 237(3), 881-887.

Todd, K. J., Slatter, C. A., \& Ali, D. W. (2004). Activation of ionotropic glutamate receptors on peripheral axons of primary motoneurons mediates transmitter release at the zebrafish NMJ. Journal of Neurophysiology, 91(2), 828-840. https://doi.org/10.1152/jn.00599.2003

Tran, S. \& Gerlai, R. (2015). Thirty-second net stressor task in adult zebrafish. Bio-Protocol, 5(5), e1413. https://doi.org/10.21769 /bioprotoc. 1413

Tuomisto, L., \& Tacke, U. (1986). Is histamine an anticonvulsive inhibitory transmitter? Neuropharmacology, 25(8), 955-958. https://doi.org/10.1016/0028-3908(86)90029-8

Yazulla, S., \& Studholme, K. M. (2001). Neurochemical anatomy of the zebrafish retina as determined by immunocytochemistry. Journal of Neurocytology, 30, 551-592. https://doi.org/10.1007 /978-1-4615-1089-5_2

Ying, Z., Babb, T. L., Comair, Y. G., Bushey, M., \& Touhalisky, K. (1998). Increased densities of AMPA GluR1 subunit proteins and presynaptic mossy fiber sprouting in the fascia dentata of human hippocampal epilepsy. Brain Research, 798(1-2), 239246. https://doi.org/10.1016/s0006-8993(98)00421-1

Received: August 08, 2019

Accepted: November 18, 2019

Published: December 12, 2019 